\title{
DAMPAK LATIHAN YOGA TERHADAP KUALITAS HIDUP DAN PSIKOLOGI IBU NIFAS
}

\author{
Lastri Mei Winarni ${ }^{1}$, Marthia Ikhlasiah², Rini Sartika ${ }^{3}$ \\ 1Dosen Program Studi DIII Kebidanan, STIKes Yatsi Tangerang \\ Email : meidilastri@gmail.com \\ ${ }^{2}$ Dosen Program Studi DIII Kebidanan, Universitas Muhammadiyah Tangerang \\ Email :marthiaiik@gmail.com \\ ${ }^{3}$ Dosen Program Studi DIII Kebidanan, STIKes Yatsi Tangerang \\ Email : rsartika79@yahoo.com
}

\begin{abstract}
Background: Most mothers during childbirth experienced a decline in physical, psychological and social conditions during their new roles as mothers. This will affect the quality of life and psychological condition. Yoga is an alternative to complementary therapy to help improve the quality of life and stabilize the psychological condition of the mother.

Purpose : This study aims to determine the impact of yoga practice on quality and psychological postpartum mothers.

Method : research design using quasi-experimental, with the type of pre-test and post-test quasi experimental design. Respondents in this study were all postpartum mothers one to six weeks postpartum with 54 respondents divided into two groups, namely the control group and the treatment group each of 27 respondents. The treatment group got intervention in the form of yoga practice for four sessions, each session 30 minutes for four weeks postpartum. Both groups will be measured quality of life using the WHOQBREF questionnaire twice and their psychological condition measured using EPDS four times.

Results of this study are an increase in the quality of life of postpartum mothers who practice yoga with a $Z$ score of 4,329 compared to mothers who do not do yoga with a value of 1,727 and a decrease in the value of the postpartum depression scale in mothers who do yoga with a $Z$ score of 4.311 compared to mothers who do not do yoga with a value of 0.687 .

Conclusion : yoga can be an alternative midwifery care for postpartum mothers.

Sugestion Midwives can teach yoga to complement midwifery care for postpartum mothers to improve the quality of life and decrease the value of the postpartum depression scale on the psychological condition of the postpartum mothers.
\end{abstract}

Keywords : yoga, quality of life, psychological condition, postpartum mother

\section{ABSTRAK}

Latar Belakang : Sebagian besar ibu pada masa nifas mengalami penurunan kondisi fisik, psikologi dan sosial selama menjalankan peran barunya sebagai ibu. Hal ini akan berpengaruh pada kualitas hidup dan kondisi psikologisnya. Yoga menjadi salah satu alternatif terapi komplementer untuk membantu meningkatkan kualitas hidup dan menstabilkan kondisi psikologis ibu. ibu nifas.

Tujuan : Penelitian ini bertujuan untuk mengetahui dampak latihan yoga terhadap kualitas dan psikologis

Metode : desain penelitian menggunakan kuasi eksperimen, dengan jenis pre test and post test quasi experimental design. Subjek penelitian ini adalah seluruh ibu nifas satu sampai enam minggu pasca persalinan sejumlah 54 responden yang dibagi menjadi dua kelompok, yaitu kelompok kontrol dan kelompok perlakuan masing-masing 27 responden. Kelompok perlakuan mendapatkan intervesi berupa latihan yoga selama empat sesi, masing-masing sesi 30 menit selama empat minggu masa nifas. Kedua kelompok akan diukur kualitas hidup menggunakan kuesioner WHOQBREF sebanyak dua kali dan diukur kondisi psikologisnya menggunakan EPDS sebanyak empat kali.

Hasil penelitian ini adalah terdapat peningkatan meningkatnya kualitas hidup ibu nifas yang latihan yoga dengan nilai $Z$ Score 4.329 dibandingkan ibu yang tidak melakukan yoga dengan nilai 1.727 dan menurunnya nilai skala depresi pada kondisi psikologis ibu yang melakukan yoga dengan nilai Z Score 4.311 dibandingkan ibu yang tidak melakukan yoga dengan nilai 0.687 . 
Kesimpulan : yoga dapat menjadi alternatif asuhan kebidanan untuk ibu masa nifas.

Saran Bidan dapat mengajarkan yoga untuk melengkapi asuhan kebidanan pada ibu nifas untuk meningkatkan kualitas hidup dan menurunkan nilai skala depresi pospartum pada kondisi psikologis ibu nifas.

Kata Kunci : Yoga, Kualitas Hidup, Kondisi Psikologi, Ibu Nifas

\section{PENDAHULUAN}

Pada masa nifas ibu mengalami proses adaptasi untuk membantu tubuh memulihkan diri setelah persalinan. Proses adaptasi pada ibu nifas dibagi menjadi dua, yaitu adaptasi fisiologis dan adaptasi psikologis.(Haran, van Driel, Mitchell, \& Brodribb, 2014) Adaptasi fisiologis meliputi proses kembalinya kondisi fisik dan sistem organ tubuh ibu seperti sebelum hamil, sedangkan adaptasi psikologis meliputi perubahan emosional dan kesehatan mental.(Haran et al., 2014; Miller, Pallant, \& Negri, 2006; O'Hara, 2009) Oleh karena itu ibu nifas mengalami penurunan kualitas hidup dari segi fisik, psikologis, dan sosial dari kondisi sebelumnya karena peran barunya.(Haran et al., 2014; Zubaran et al., 2009) Tanggung jawab untuk melakukan perannya sebagai ibu baru, perawatan bayi dan keluarganya serta proses pemulihan pasca persalinan membuat ibu cukup rentan mengalami resiko infeksi, penurunan daya tahan tubuh, perubahan mood atau perubahan perilaku yang terkait dengan kondisi tubuh dan psikologinya.(Haran et al., 2014; Milani et al., 2017)

Kualitas hidup ibu nifas merupakan sebuah konsep kepuasan dan kesejahteraan yang ibu alami selama masa nifas dengan indikator status kesehatan, persepsi, kondisi kehidupan, psikologis, sosial, gaya hidup dan kebahagiaan.(Afiyanti, n.d.; Sadat, Abedzadeh-kalahroudi, \& Atrian, 2014; Theofilou, 2013) World Health Organization (WHO) mendefinisikan kualitas hidup sebagai persepsi individu mengenai budaya, sistem nilai yang mereka alami dalam hidup yang berhubungan dengan tujuan, harapan, standar, dan fokus hidup mereka. Kualitas hidup merupakan konsep yang luas dan kompleks terhadap kesehatan fisik seseorang, kondisi psikologi, kepercayaan personal, hubungan sosial, dan timbal baliknya dengan lingkungan.(Post, 2014; Theofilou, 2013; Ventegodt, Merrick, \& Andersen, 2003) Kualitas hidup ibu merupakan kehidupan yang dijalani ibu dengan baik dan kualitas tinggi, yang mencakup kepuasan hidup, kebahagiaan, memahami mengenai makna kehidupan, sistem informasi biologis, menyadari potensi kehidupan, terpenuhinya kebutuhan hidup, dan faktor objektif yang lain.(Ventegodt et al., 2003)
Komponen yang termasuk ke dalam penilaian kualitas hidup adalah kepuasan hidup, kondisi kesehatan, aktivitas sehari-hari, hubungan dengan keluaarga dan teman, pekerjaan, lingkungan dan perasaan negatif. (Hill \& Schools, 2018; Theofilou, 2013) Indikator kualitas hidup manusia dibedakan menjadi empat dimensi, yaitu dimensi fisik, dimensi psikologis, dimensi sosial, dan dimensi lingkungan. Keempat dimensi tersebut sangat mempengaruhi kualitas hidup seseorang, semakin tinggi nilai keempat dimensi tersebut, maka semakin baik kualitas hidup orang tersebut. Kualitas hidup yang rendah dapat mengakibat dampak serius bagi ibu dan keluarganya, sebagai contoh ibu tidak dapat merawat dirinya sendiri, bayi dan keluarganya. Penelitian mengenai kualitas hidup pada ibu nifas di Indonesia belum banyak dipublikasikan. Selain kualitas hidup ibu nifas, kondisi psikologis ibu nifas juga perlu mendapat perhatian. Kondisi psikologis ibu masa nifas adalah serangkaian perasaan dan emosi yang dirasakan oleh ibu selama masa nifas yang menggambarkan kenyamanan dan ketidaknyamanan dan akan mempengaruhi perilakunya dalam kehidupan sehari-hari.(Bahiyatun, 2013; Lubis, 2009)

Berdasarkan studi pendahuluan dari 20 orang ibu nifas dua sampai empat minggu yang diwawancarai $65 \%$ ibu merasa tidak puas dengan kesehatannya, $100 \%$ ibu mengalami kelelahan secara fisik, $100 \%$ ibu mengalami kurang tidur, $80 \%$ ibu menyatakan minim memiliki waktu berdua dengan pasangan dan sahabat, $12 \%$ mengalami gangguan psikologi ringan selama 2 minggu pertama masa nifas. Gangguan psikologi ringan tersebut berupa rasa "down", tertekan, mudah tersinggung, mudah terluka perasaannya, sedih, dan cemas yang tidak dapat diprediksi sebelumnya. Hal itu ditambah dengan kurangnya pemahaman suami, keluarga dan sahabat mengenai cara mendukung ibu dalam melaksanakan peran barunya. Gangguan psikologis seperti ini akan mengakibatkan hambatan pada interaksi antara ibu dengan bayi baru lahir, sehingga menyulitkan hubungan interpersonal, komunikasi diantara ibu dan bayi dan tumbuh kembang bayi selanjutnya.(Moberg \& Prime, 2013) hal tersebut dapat mempengaruhi kualitas hidup ibu sendiri serta keluarganya.(Sadat et al., 2014) 
Oleh karena itu ibu memerlukan sistem dukungan yang cukup baik untuk membantu mengatasi permasalahannya tersebut. Saat ini road map penelitian mengenai sistem dukungan untuk ibu masa nifas belum banyak dikaji, cara-cara efektif untuk membantu ibu mengatasi gangguan psikologis ringan juga belum banyak diteliti, tetapi beberapa penelitian telah mengidentifikasi bahwa dukungan suami memiliki hubungan signifikan untuk mengurangi kejadian depresi postpartum ibu masa nifas. (Fatimah, 2010; Kurniasari \& Astuti, 2015; Winarni, 2018) Zlotnick dkk menjelaskan keberhasilan terapi konseling interpersonal selama empat kali pada ibu nifas untuk mengurangi kejadian depresi postpartum,(Zlotnick, Johnson, Miller, Pearlstein, \& Howard, 2001) sedangkan Munoz dkk melakukan terapi manajemen mood dan perilaku kognitif serta menggabungkan konsep pembelajaran sosial, teori kelekatan (attachment) dan sosial budaya menjadi pelatihan ibu dan bayi untuk mencegah munculnya gejala gangguan depresi pada ibu nifas. (Muñoz et al., 2007)

Beberapa peneliti telah melakukan pengkajian terhadap model maupun tata laksana untuk mengatasi gangguan psikologi masa nifas, diantaranya meningkatkan peran dukungan suami,(Fatimah, 2010; Kurniasari \& Astuti, 2015; Winarni, 2018) pelatihan khusus untuk ibu dan bayi, terapi konseling, (Zlotnick et al., 2001) manajemen mood dan perilaku,(Muñoz et al., 2007) serta yoga.(Bridges \& Sharma, 2017; Melissa Mercedes Buttner, 2013; Y.-L. Ko, Lin, Yang, Chen, \& Shih, 2015) Peneliti tertarik mendalami yoga karena berdasarkan pengalaman pribadi, yoga dapat membantu menurunkan tingkat stress dan emosi. Kamei dkk dalam penelitannya menjelaskan bahwa setelah yoga, diketahui serum kortisol dalam darah akan menurun dan mengubah gelombang otak menjadi gelombang alpha (a).(Kamei et al., 2000) Gelombang alpha merupakan gelombang di otak yang berada pada frekuensi $8-13 \mathrm{~Hz}$. Biasanya gelombang ini muncul pada saat manusia beristirahat dengan memejamkan mata, diawal menjelang tidur.(Aminoff, 2012)

Yoga juga dapat meningkatkan kualitas hidup, Woodyard menjelaskan bahwa melakukan yoga secara teratur dapat mengurangi rasa nyeri secara fisik, menguatkan otot-otot tubuh, menurunkan stress, emosi, kecemasan serta membantu proses penyembuhan dari sakit dan membantu meningkatkan kualitas hidup.(Woodyard, 2011) Kata Yoga berasal dari Bahasa Sansekerta "Yuj" yang artinya menggabungkan atau menyatukan (to join). Penyatuan ini memiliki makna bersatunya manusia dengan Sang Maha Pencipta melalui keharmonisan antara fisik, mental dan spiritual. Secara esensi yoga merupakan kesadaran manusia, semakin jernih dan murni kesadaran manusia maka semakin mulia cara berpikirnya. Sehingga yoga dapat dijadikan salah satu alternatif kegiatan fisik tubuh untuk menstabilkan emosi, menguatkan tekad dan keberanian, meningkatkan rasa percaya diri dan fokus, serta membngun afirmasi positif dan kekuatan pikiran.(Y. Ko, Yang, Fang, Lee, \& Lin, 2013; Pratignyo, 2014) Maka dari itu yoga yang dilakukan selama masa nifas diharapkan dapat membantu ibu dalam meningkatkan kualitas hidup, menguatkan otot tubuh, merelaksasi, menstabilkan emosi dan meningkatkan kepercayan dirinya menghadapi peran barunya sebagai ibu. Dengan teknik napas yang penuh kesadaran, gerakan yang lembut, relaksasi dan meditasi, yoga dapat membantu ibu meningkatkan energi dan daya tahan tubuh, melepaskan stress dan cemas, meningkatkan kualitas tidur, mengurangi ketegangan otot, dan keluhan fisik yang lain seperti : nyeri punggung, nyeri pada daerah sekitar paha dan pinggang.(Beddoe, Lee, Weiss, Powell Kennedy, \& Yang, 2010; Bridges \& Sharma, 2017; Y.-L. Ko et al., 2015).

Oleh karena itu penelitian bertujuan untuk mengetahui dampak latihan yoga terhadap kualitas hidup dan kondisi psikologi pada ibu nifas.

\section{METODE Identifikasi Variabel}

Desain penelitian yang digunakan dalam penelitian ini adalah kuasi eksperimen, dengan jenis pre test and post test quasi experimental design, dan pendekatan cross sectional. Variabel yang diteliti adalah kualitas hidup dan kondisi ibu nifas. Penelitian ini membandingkan nilai mean hasil kuesioner kualitas hidup dan kondisi psikologis ibu nifas pada kelompok kontrol dengan kelompok perlakuan. Responden akan berpartisipasi dalam penelitian ini sekitar 4-8 minggu pascapersalinan. Penelitian ini dilakukan di tiga klinik dan praktik mandiri bidan di Kota Tangerang antara Maret Agustus 2019.

\section{Subjek Penelitian}

Subjek pada penelitian ini adalah ibu nifas satu minggu sampai 6 minggu pasca persalinan sejumlah 54 responden yang dibagi menjadi dua kelompok, yaitu kelompok kontrol dan kelompok perlakuan. Kelompok kontrol merupakan ibu nifas yang tidak diberi pelatihan yoga lalu diukur tingkat kualitas hidup sebanyak dua kali dan kondisi psikologisnya sebanyak empat kali selama masa 
nifas, sedangkan kelompok perlakuan adalah sekelompok ibu nifas yang akan diberikan latihan yoga selama empat sesi, setiap sesi dilakukan selama 30 menit. Pengukuran kualitas hidup kelompok perlakuan dilakukan sebanyak dua kali, yaitu sebelum dilakukan perlakuan, dan setelah perlakuan selesai, sedangkan kondisi psikologi dilakukan sebanyak empat kali, yaitu pada satu minggu pasca persalinan, dua minggu pasca persalinan, tiga minggu pasca persalinan, dan empat minggu pasca persalinan.

Kriteria inklusi kelompok kontrol adalah ibu yang bersedia berpartisipasi dalam penelitian ini. Kriteria eksklusi kelompok kontrol adalah ibu yang tidak dapat memenuhi pengukuran selanjutnya. Pada kelompok intervensi, kriteria inklusi yang diberlakukan adalah ibu nifas yang bersedia berpartisipasi, bersedia mengikuti empat sesi latihan yoga, memenuhi pengukuran variabel kualitas hidup dan kondisi psikologis dengan lengkap. Kriteria eksklusi pada kelompok perlakuan adalah ibu yang tidak dapat melanjutkan sesi yoga, ibu yang mengalami komplikasi serius sehingga tidak dapat melakukan yoga, dan ibu yang tidak memenuhi pengukuran variabel kualitas hidup dan kondisi psikologis dengan lengkap

\section{Intervensi}

Latihan yoga diberikan sebanyak empat sesi kepada ibu nifas, setiap sesinya memerlukan waktu selama 30 menit dengan jeda antara sesi pertama ke sesi selanjutnya adalah minimal satu minggu. Latihan yoga dilakukan secara individu dan dibimbing oleh fasilitator yang telah tersertifikasi sebagai guru yoga. Waktu untuk latihan yoga disesuaikan oleh permintaan responden dengan jadwal pagi antara Pkl 10.00 s.d 10.30 dan jadwal sore antara Pkl 16.00 s.d 16.30 Selama intervensi terdapat lima responden yang dieksklusi karena tidak dapat memenuhi latihan yoga.

\section{Instrumen Penelitian}

Instrumen yang digunakan dalam penelitian ini adalah kuesioner kualitas hidup dari
The World Health Organization Quality of Life (WHOQOL-BREF) dan kuesioner pengukuran kondisi psikologis dengan Edinburgh Postnatal Depression Scale (EPDS). Kuesioner WHOQOLBREF memiliki 26 pertanyaan yang terdiri dari empat dimensi yaitu dimensi fisik (Q3, Q4, Q10, Q15, Q16, Q17, Q18), dimensi psikologi (Q5, Q6, Q7, Q11, Q19, Q26), dimensi sosial (Q20, Q21, Q22), dan dimensi lingkungan (Q8, Q9, Q12, Q13, Q14, Q23, Q24, Q25). Kuesioner WHOQOL-BREF menggunakan Bahasa Indonesia dan sudah baku, sehingga tidak perlu uji validitas dan reliabilitas. Untuk kuesioner EPDS memiliki 10 pertanyaan mengenai pengukuran kondisi psikologi ibu postpartum telah mendapatkan nilai sensitivitasnya $80 \%$ dan spesivitasnya $78 \%$.(Machmudah, 2010)

\section{Analisis Statistik}

Analisis data menggunakan software IBM SPSS Statistic dengan mencari informasi dasar seperti frekuensi, persentase, rata-rata, dan standar deviasi. Uji normalitas data masing-masing kelompok menggunakan Shapiro-Wilk, dihasilkan untuk variabel dimensi fisik, dimensi psikologis, dimensi sosial, dan dimensi lingkungan berdistribusi normal sehingga menggunakan uji T berpasangan. Varibel kualitas hidup dan kondisi psikologi berdistribusi tidak normal sehingga menggunakan uji Wilcoxon

\section{Etika Penelitian}

Etika penelitian yang diterapkan pada penelitian ini ada tiga, yaitu respect for person, beneficence and non maleficence, serta justice. Sebelum mengikuti penelitian ini setiap responden dijelaskan mengenai prosedur, tujuan, dan manfaat penelitian. Responden boleh tidak ikut serta dalam penelitian ini, dan tetap akan mendapatkan asuhan kebidanan yang sama. Jika responden mengajukan keberatan dalam proses pengumpulan data, responden dapat mengundurkan diri sewaktuwaktu. Semua responden akan diperlakukan sama dan tidak dibeda-bedakan.

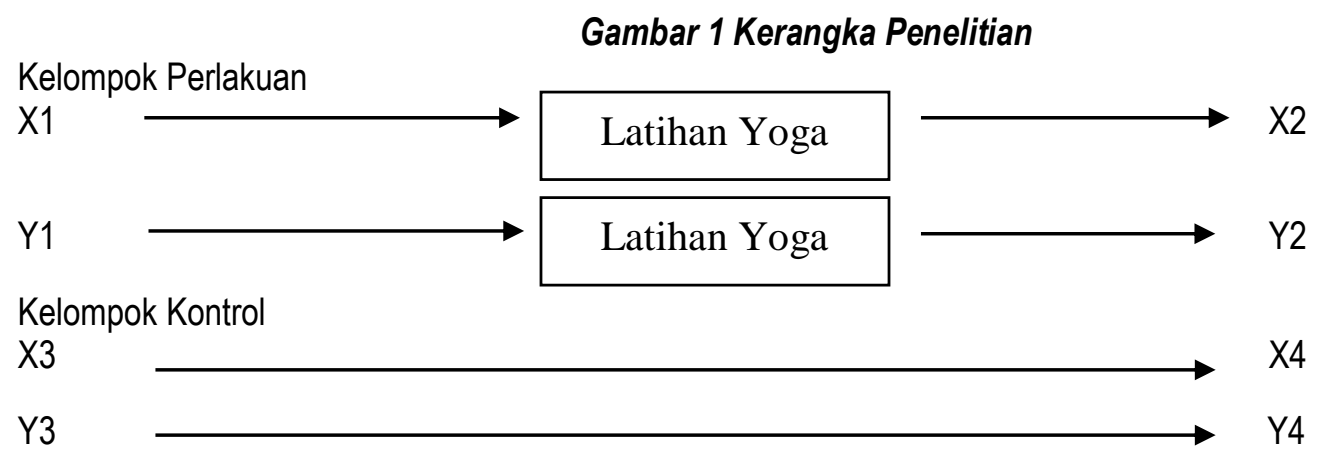




\section{Keterangan :}

X1 : Nilai kualitas hidup pada kelompok intervensi sebelum latihan yoga

X2 : Nilai kualitas hidup pada kelompok intervensi setelah latihan yoga

X3 : Nilai kualitas hidup pada kelompok kontrol pada pengukuran pertama

X4 : Nilai kualitas hidup pada kelompok kontrol pada pengukuran kedua

Y1 : Nilai kondisi psikologi pada kelompok intervensi sebelum latihan yoga

Y2 : Nilai kondisi psikologi pada kelompok intervensi setelah latihan yoga

Y3 : Nilai kondisi psikologi pada kelompok kontrol pada pengukuran pertama

Y4 : Nilai kondisi psikologi pada kelompok kontrol pada pengukuran kedua

\section{Gambar 2 Skema pemilihan responden}

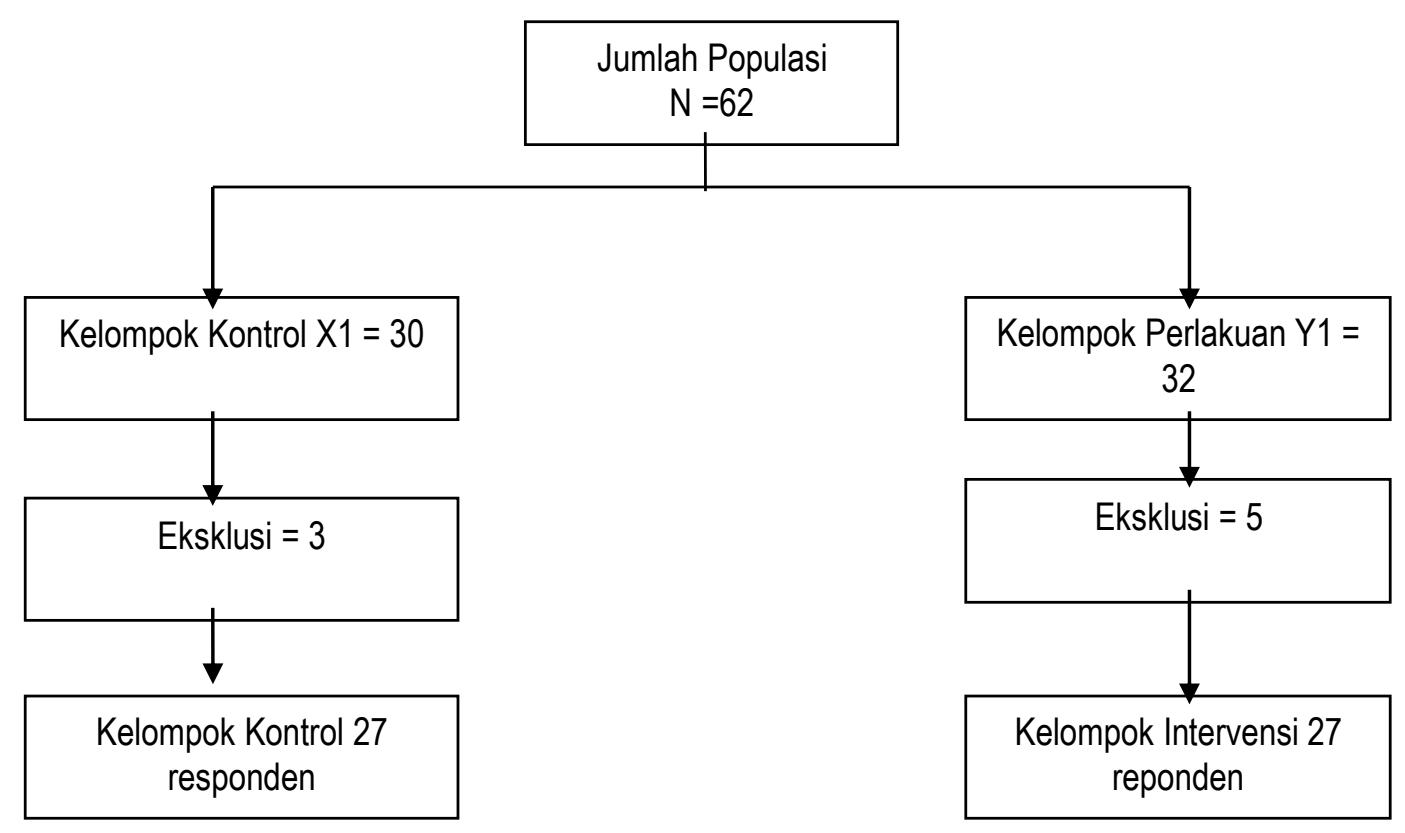

HASIL DAN PEMBAHASAN

Berdasarkan analisis data didapatkan hasil sebagai berikut :

Tabel 1 Distribusi Frekuensi Karakteristik Ibu Nifas ( $n=54)$

\begin{tabular}{lcc}
\hline \multicolumn{1}{c}{ Karakteristik } & Jumlah & Persentase (\%) \\
\hline Paritas & & \\
Primipara & 19 & 35.2 \\
$\quad$ Multipara & 35 & 64.8 \\
Pekerjaan & & \\
$\quad$ Bekerja & 24 & 44.4 \\
$\quad$ Tidak bekerja & 30 & 55.6 \\
Pendapatan & & \\
$\quad<3.600 .000$ & 25 & 46.3 \\
$\geq 3.600 .000$ & 29 & 53.7 \\
\hline
\end{tabular}

Berdasarkan tabel 1 diketahui bahwa $64.8 \%$ responden adalah ibu multipara, $55.6 \%$ ibu tidak bekerja, dan $46.7 \%$ ibu memiliki pendapatan < Rp. 3.600 .000 
Tabel 2 Rerata Dimensi Kualitas Hidup Ibu Nifas $(n=54)$

\begin{tabular}{|c|c|c|c|c|c|c|c|c|}
\hline \multirow{2}{*}{ Rerata } & \multicolumn{2}{|c|}{ Kelompok Kontrol } & \multirow{2}{*}{ Selisih } & \multirow{2}{*}{$\begin{array}{c}p \\
\text { value }\end{array}$} & \multicolumn{2}{|c|}{ Kelompok Perlakuan } & \multirow{2}{*}{ Selisih } & \multirow{2}{*}{$p$ value } \\
\hline & Pre & Post & & & Pre & Post & & \\
\hline Dimensi Fisik & 61.3 & 58.7 & -2.6 & .001 & 56.1 & 61.3 & 5.2 & .015 \\
\hline Dimensi Psikologis & 41.6 & 41.9 & 0.3 & .675 & 43.3 & 58.7 & 15.4 & .000 \\
\hline Dimensi Sosial & 64.6 & 66.5 & 1.9 & .089 & 55 & 55.2 & 0.2 & .327 \\
\hline Dimensi Lingkungan & 47.7 & 50.7 & 3 & .001 & 50.5 & 52.3 & 1.8 & .008 \\
\hline
\end{tabular}

\section{Dimensi Fisik}

Berdasarkan tabel 2 diketahui bahwa terdapat peningkatan rerata dimensi fisik senilai 5.2 pada kelompok perlakuan dibandingkan dengan kelompok kontrol dengan $p$ value 0.015 . Oleh karena itu dapat terdapat perbedaan nilai dimensi fisik sebelum dan sesudah latihan yoga.

Selama masa nifas ibu sering mengeluh kelelahan, pusing, nyeri disekitar punggung dan pinggang, kurang tidur yang menyebabkan badan tidak nyaman dan lemas. Hal ini terlihat pada rendahnya nilai ukur pada dimensi fisik sebelum dilakukan intervensi sebesar 56.1, kemudian kelompok perlakuan mengikuti yoga selama empat sesi dan diukur nilai dimensi fisiknya dengan hasil menjadi 61.3, lebih tinggi dibandingkan nilai dimensi fisik pada kelompok kontrol 61.3 pada pengukuran pertama menjadi 58.7 pada pengukuran kedua.

$\mathrm{Hal}$ ini sesuai dengan penelitian Melissa dkk yang menyatakan bahwa gerakan yoga merupakan proses menyatukan antara teknik pernafasan, relaksasi, dan harmonisasi pada tubuh dan pikiran dapat mengurangi rasa tidak nyaman, nyeri di daerah kepala, punggung, pinggang, tangan dan kaki, serta melancarkan peredaran darah.(Melissa M Buttner, Brock, O'Hara, \& Stuart, 2015; Narasimhan, Nagarathna, \& Nagendra, 2011; Woodyard, 2011) Salah satu gerakan yoga dalam penelitian ini adalah meditasi, yaitu dengan cara duduk bersila dengan posisi kaki tidak bertumpuk dan meletakkan di daerah dada dan perut. Postur ini bernama Sukhasana dapat bekerja pada aspek fisik, emosional, mental dan spiritual, sehingga tubuh memiliki waktu untuk beristirahat dan mengatur kembali kerja organ-organ tubuhnya.(Russell, Daniels, Smoot, \& Allen, 2019)

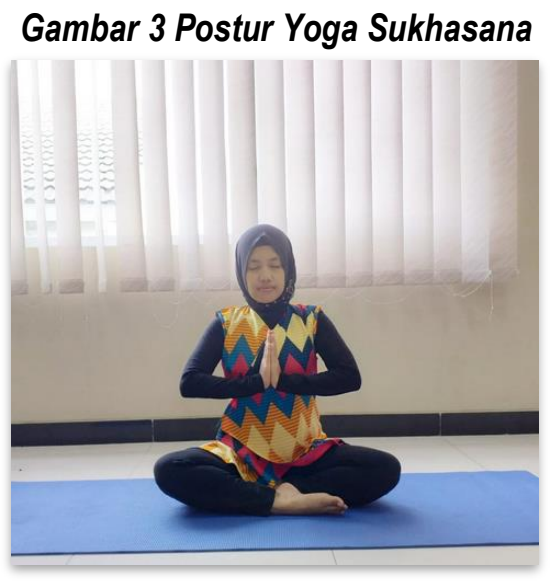

Postur lain yang dapat membantu memulihkan fisik ibu, mengurangi nyeri leher bahu dan tulang belakang (punggung sampai ke pinggang) adalah Bilikasana 1 (Cat and Cow), gerakan gabungan antara melengkukan dan menggembungkan punggung dapat merelaksasi dan meregangkan otot sekitar leher, punggung dan pinggang.

\section{Gambar 4 Bilikasana 1}
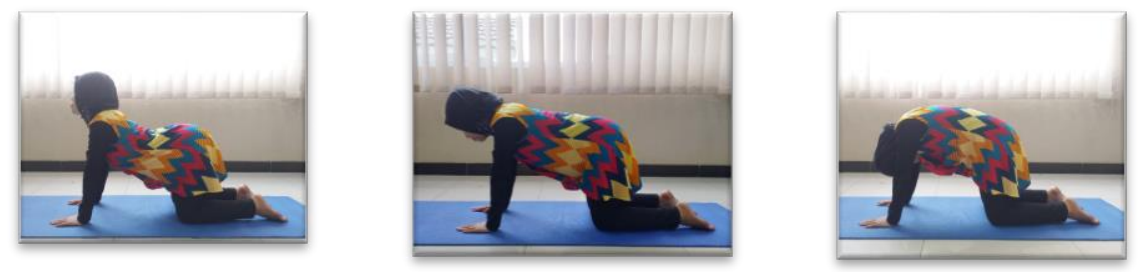

\section{Dimensi Psikologi}

Berdasarkan tabel 2 diketahui bahwa terdapat peningkatan rerata dimensi psikologi senilai 15.4 pada kelompok perlakuan dibandingkan dengan kelompok kontrol yang meningkat 0.3 dengan $p$ value 0.000 . Oleh karena itu dapat terdapat perbedaan nilai dimensi psikologi sebelum dan sesudah latihan yoga 
Selama masa nifas ibu sering mengeluh sedih, sensitif dalam menerima ucapan orang lain meskipun hanya bercanda, mudah tersinggung, menangis, dan kesal. Hal ini terlihat rendahnya nilai dimensi psikologi kelompok perlakuan dengan nilai 47.3 dan meningkat menjadi 58.7 setelah mengikuti yoga, dibandingkan dengan kelompok kontrol pada pengukuran pertama nilai rerata adalah 41.6 menjadi 41.9, terdapat peningkatan namun tidak signifikan.

Hal ini dapat diasumsikan postur yoga, meditasi dan teknik pernafasan membantu menurunkan tingkat stress ibu selama masa nifas. Meditasi dan teknik pernafasan dalam yoga dapat membantu tubuh dalam menenangkan dan memfokuskan pikiran dalam membangun kesadaran diri dan mengurangi kecemasan, kemarahan, kekhawatiran, serta kesedihan.(Miller et al., 2006; Narasimhan et al., 2011; Woodyard, 2011) Postur yang dapat menggabungkan antara meditasi, relaksasi dan pernafasan sehingga memelihara kestabilan dan keseimbangan emosi adalah Balasana (Child Pose)

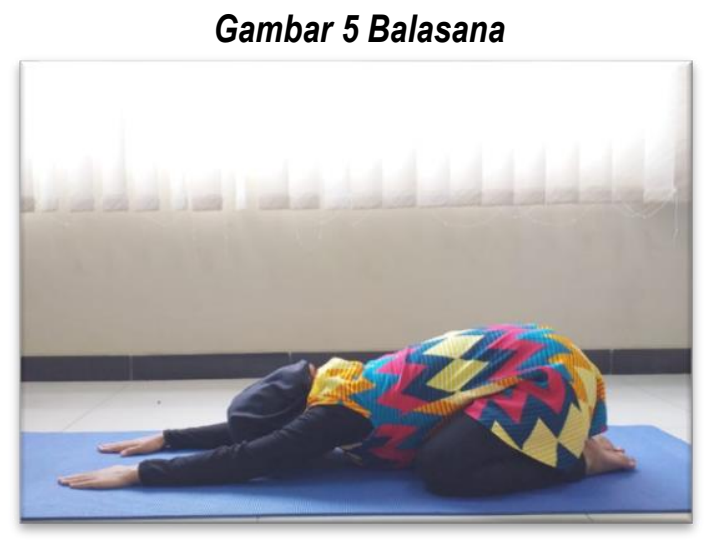

\section{Dimensi Sosial}

Berdasarkan tabel 1.2 diketahui bahwa terdapat peningkatan rerata dimensi sosial senilai 55 pada kelompok perlakuan menjadi 55.2 tidak jauh berbeda dengan kelompok kontrol pada pengukuran pertama nilai rerata adalah 64.6 menjadi 66.5 , terdapat peningkatan namun tidak signifikan dengan $p$ value 0.327 . Oleh karena itu dapat tidak terdapat perbedaan nilai dimensi sosial sebelum dan sesudah latihan yoga.

Hal tersebut dikarenakan ibu masih dalam masa nifas sehingga seluruh waktunya difokuskan untuk pemulihan diri, melakukan perannya sebagai ibu baru dan melakukan perawatan bayinya yang baru lahir.

\section{Dimensi Lingkungan}

Berdasarkan tabel 1.2 diketahui bahwa terdapat peningkatan rerata dimensi lingkungan senilai 50.5 pada kelompok perlakuan menjadi 52.3 tidak jauh berbeda dengan kelompok kontrol pada pengukuran pertama nilai rerata adalah 47.7 menjadi 50.7, terdapat peningkatan namun tidak signifikan dengan $p$ value 0.008 . Oleh karena itu dapat terdapat perbedaan nilai dimensi sosial sebelum dan sesudah latihan yoga.

Asumsi peneliti berubahnya nilai rerata dimensi lingkungan merupakan refleksi dari proses penerimaan dan kesadaran ibu mengenai kesehatan, kenyamanan dan keamanan lingkungannya. Secara umum yoga dapat meningkatkan kesadaran dan membuat pola pikir menjadi lebih sederhana, menerima apa yang ada sebagai karunia, meningkatkan kepercayaan diri bagi ibu, karena prinsip yoga adalah menyatukan tubuh, pikiran dan spiritual untuk meningkatkan aspek kesehatan. (Woodyard, 2011)

Tabel 3 Rerata Kualitas Hidup dan Kondisi Psikologi Ibu Postpartum ( $n=54$ )

\begin{tabular}{|c|c|c|c|c|c|c|c|c|}
\hline \multirow{2}{*}{ Rerata } & \multicolumn{2}{|c|}{ Kualitas Hidup } & \multirow{2}{*}{ Z Score } & \multirow{2}{*}{$p$ value } & \multicolumn{2}{|c|}{ Kondisi Psikologi } & \multirow{2}{*}{$\begin{array}{c}Z \\
\text { Score }\end{array}$} & \multirow{2}{*}{$p$ value } \\
\hline & Pre & Post & & & Pre & Post & & \\
\hline Kelompok Kontrol & 73.3 & 73.7 & -1.727 & .084 & 9.4 & 9.2 & -.687 & .492 \\
\hline Kelompok Perlakuan & 72.1 & 76.7 & -4.329 & .000 & 9.6 & 7.1 & -4.311 & .000 \\
\hline
\end{tabular}

\section{Kualitas Hidup}

Berdasarkan tabel 1.3 diketahui bahwa terdapat nilai Z Score kualitas hidup kelompok perlakuan 4.329 lebih tinggi dibandingkan kelompok kontrol 1.727, sehingga dapat disimpulkan terdapat dampak positif pada kualitas hidup kelompok perlakuan dengan nilai $p$ value 0.000 dibandingkan dengan kelompok kontrol dengan nilai $p$ value 0.084 .
Hal ini didukung pada penelitian sebelumnya bahwa sesorang yang berlatih yoga teratur dapat meningkat kualitas hidupnya. (Kamei et al., 2000; Y.-L. Ko et al., 2015; Woodyard, 2011) Penelitian juga menjabarkan bahwa yoga dapat mengurangi tingkat stress dan kecemasan yang merupakan penyebab pendukung terjadinya stroke, penyakit jantung, hipertensi dan diabetes melitus.(Narasimhan et al., 2011; Woodyard, 2011) 
Berkurangnya stress dapat membantu menurunkan terjadinya penyakit-penyakit degeneratif, sehingga seseorang yang tidak memiliki penyakit degeneratif kualitas hidupnya lebih baik.

Upaya yang dapat dilakukan oleh bidan untuk meningkatkan kualitas hidup ibu nifas adalah pemantauan dengan melakukan kunjungan nifas minimal tiga kali dalam enam minggu, pemberian pendidikan kesehatan dan anticipatory guidance untuk ibu nifas, serta asuhan kebidanan komprehensif pada ibu nifas.(Haran et al., 2014; Milani et al., 2017) Pelaksanaan yoga pada ibu nifas dapat digabungkan dengan kunjungan nifas.

\section{Kondisi Psikologis}

Berdasarkan tabel 1.3 diketahui bahwa terdapat nilai Z Score kondisi psikologis kelompok perlakuan 4.311 lebih tinggi dibandingkan kelompok kontrol 0.687 , sehingga dapat disimpulkan terdapat dampak positif pada kondisi psikologis kelompok perlakuan dengan nilai $p$ value 0.000 dibandingkan dengan kelompok kontrol dengan nilai $p$ value 0.492 .

Yoga dapat membantu ibu nifas untuk dapat relaksasi ditengah kesibukan peran barunya sebagai ibu yang merawat bayi baru lahir dan mengurus keluarga. Nafas perlahan, fokus dalam melaksanakan postur, mengheningkan pikiran dan menghadirkan kesadaran diri pada saar sekarang membantu menyeimbangkan sistem syaraf dan mekanisme pertahanan diri. (Bridges \& Sharma, 2017; Woodyard, 2011) oleh karena itu yoga dapat membantu meningkatkan kepercayaan diri dan membantu optimisme ibu dalam menghadapi setiap persoalan yang muncul pada kesehatannya, maupun kondisi emosionalnya. (Arora \& Bhattacharjee, 2008)

\section{SIMPULAN}

Berdasarkan hasil penelitian dapat ditarik kesimpulan bahwa terdapat dampak berupa peningkatan meningkatnya kualitas hidup ibu nifas dengan nilai Z Score 4.329 dibandingkan ibu yang tidak melakukan yoga dengan nilai 1.727 dan menurunnya nilai skala depresi pada kondisi psikologis ibu yang melakukan yoga dengan nilai Z Score 4.311 dibandingkan ibu yang tidak melakukan yoga dengan nilai 0.687 .

\section{SARAN}

Bidan dapat mengajarkan yoga untuk melengkapi asuhan kebidanan pada ibu nifas untuk meningkatkan kualitas hidup dan menurunkan nilai skala depresi pospartum pada kondisi psikologis ibu nifas.

\section{DAFTAR PUSTAKA}

Afiyanti, Y. (n.d.). Analisis konsep kualitas hidup. Jurnal Keperawatan Indonesia, 13(2), 8186.

Aminoff, M. J. (2012). Chapter 3 Electroencephalography: General Principles and Clinical Applications (M. J. B. T.-A. E. in C. N. (Sixth E. Aminoff, ed.). https://doi.org/https://doi.org/10.1016/B9781-4557-0308-1.00003-0

Arora, S., \& Bhattacharjee, J. (2008). Modulation of immune responses in stress by Yoga. International Journal of Yoga, 1(2), 45-55. https://doi.org/10.4103/0973-6131.43541

Bahiyatun, S. P. (2013). Buku Ajar Asuhan Kebidanan Nifas Normal. EGC.

Beddoe, A. E., Lee, K. A., Weiss, S. J., Powell Kennedy, H., \& Yang, C.-P. P. (2010). Effects of mindful yoga on sleep in pregnant women: a pilot study. Biological Research for Nursing, 11(4), 363-370.

Bridges, L., \& Sharma, M. (2017). The Efficacy of Yoga as a Form of Treatment for Depression. 22(4), 1017-1028. https://doi.org/10.1177/2156587217715927

Buttner, Melissa M, Brock, R. L., O'Hara, M. W., \& Stuart, S. (2015). Efficacy of yoga for depressed postpartum women: a randomized controlled trial. Complementary Therapies in Clinical Practice, 21(2), 94-100.

Buttner, Melissa Mercedes. (2013). Efficacy of Yoga for Depressed Postpartum Women: a Randomized Controlled Trial.

Fatimah, S. (2010). Hubungan dukungan suami dengan kejadian postpartum blues pada ibu primipara di ruang Bugenvile RSUD Tugurejo Semarang. Universitas Diponegoro.

Haran, C., van Driel, M., Mitchell, B. L., \& Brodribb, W. E. (2014). Clinical guidelines for postpartum women and infants in primary care-a systematic review. BMC Pregnancy and Childbirth, 14(1), 51. https://doi.org/10.1186/1471-2393-14-51

Hill, P. D., \& Schools, H. S. (2018). Maternal Postpartum Quality of Life Questionnaire. (February https://doi.org/10.1891/jnm-v14i3a005

Kamei, T., Toriumi, Y., Kimura, H., Kumano, H., Ohno, S., \& Kimura, K. (2000). Decrease in serum cortisol during yoga exercise is correlated with alpha wave activation. Perceptual and Motor Skills, 90(3), 10271032.

Ko, Y.-L., Lin, P.-C., Yang, C.-L., Chen, C.-P., \& Shih, H.-J. (2015). Pilot Study on an 
Integrated Pilates and Yoga Program for Decreasing Postpartum Depression in Women. Open Journal of Nursing, 5(10), 885.

Ko, Y., Yang, C., Fang, C., Lee, M., \& Lin, P. (2013). Community-based postpartum exercise program. Journal of Clinical Nursing, 22(15-16), 2122-2131.

Kurniasari, D., \& Astuti, Y. A. (2015). Hubungan antara karakteristik ibu, kondisi bayi dan dukungan sosial suami dengan postpartum blues pada ibu dengan persalinan SC di Rumah Sakit Umum Ahmad Yani Metro Tahun 2014. Jurnal Kesehatan Holistik, 9(3), 115-125.

Lubis, N. L. (2009). Depresi Tinjauan Psikologis. Jakarta: Kencana.

Machmudah. (2010). Pengaruh persalinan dengan komplikasi terhadap kemungkinan terjadinya Postpartum Blues di Kota Semarang.

Milani, H. S., Amiri, P., Mohseny, M., Abadi, A., Vaziri, S. M., \& Vejdani, M. (2017). Postpartum home care and its effects on mothers' health: A clinical trial. Journal of Research in Medical Sciences: The Official Journal of Isfahan University of Medical Sciences, 22, 96. https://doi.org/10.4103/jrms.JRMS_319_17

Miller, R. L., Pallant, J. F., \& Negri, L. M. (2006). Anxiety and stress in the postpartum: is there more to postnatal distress than depression? BMC Psychiatry, 6(1), 12.

Moberg, K. U., \& Prime, D. K. (2013). Oxytocin effects in mothers and infants during breastfeeding. Infant, 9(6), 201-206.

Muñoz, R. F., Le, H.-N., Ippen, C. G., Diaz, M. A., Urizar Jr, G. G., Soto, J., ... Lieberman, A. F. (2007). Prevention of postpartum depression in low-income women: Development of the Mamás $y$ Bebés/Mothers and Babies Course. Cognitive and Behavioral Practice, 14(1), 70-83.

Narasimhan, L., Nagarathna, R., \& Nagendra, H. (2011). Effect of integrated yogic practices on positive and negative emotions in healthy adults. International Journal of Yoga, 4(1), 13-19. https://doi.org/10.4103/0973-6131.78174

O'Hara, M. W. (2009). Postpartum depression: what we know. Journal of Clinical Psychology, 65(12), 1258-1269.

Post, M. W. M. (2014). Definitions of Quality of Life: What Has Happened and How to Move On.
Topics in Spinal Cord Injury Rehabilitation, 20(3), 167-180. https://doi.org/10.1310/sci2003-167

Pratignyo. (2014). Yoga Ibu Hamil (P. Bunda, Ed.). Depok.

Russell, N., Daniels, B., Smoot, B., \& Allen, D. D. (2019). Effects of Yoga on Quality of Life and Pain in Women With Chronic Pelvic Pain: Systematic Review and MetaAnalysis. Journal of Women's Health Physical Therapy, 43(3).

Sadat, Z., Abedzadeh-kalahroudi, M., \& Atrian, M. K. (2014). The Impact of Postpartum Depression on Quality of Life in Women After Child 's Birth. Iran Red Crescent Med J., 16(2), 1-7. https://doi.org/10.5812/ircmj.14995

Theofilou, P. (2013). Theoretical Contributions Quality of Life: Definition and Measurement. Europe's Journal of Psychology, 9(1), 150-162. https://doi.org/10.5964/ejop.v9i1.337

Ventegodt, S., Merrick, J., \& Andersen, N. J. (2003). Quality of life theory I. The IQOL theory: an integrative theory of the global quality of life concept. TheScientificWorldJournal, 3, 1030-1040.

https://doi.org/10.1100/tsw.2003.82

Winarni, L. M. (2018). PENGARUH DUKUNGAN SUAMI DAN BOUNDING ATTACHMENT DENGAN KONDISI PSIKOLOGI IBU POSTPARTUM. Jurnal IImiah Bidan, 3(2), 1-11.

Woodyard, C. (2011). Exploring the therapeutic effects of yoga and its ability to increase quality of life. International Journal of Yoga, 4(2), 49-54. https://doi.org/10.4103/09736131.85485

Zlotnick, C., Johnson, S. L., Miller, I. W., Pearlstein, T., \& Howard, M. (2001). Postpartum depression in women receiving public assistance: pilot study of an interpersonaltherapy-oriented group intervention. American Journal of Psychiatry, 158(4), 638-640.

Zubaran, C., Foresti, I. K., Schumacher, I. M. V., Cristina, I. I. L., Aline, I. I. I., \& Amoretti, L. (2009). CLINICAL SCIENCE AN ASSESSMENT OF MATERNAL QUALITY OF LIFE IN THE POSTPARTUM PERIOD IN SOUTHERN BRAZIL: A COMPARISON OF TWO QUESTIONNAIRES. Clinics, 64(8), 751756. $\quad$ https://doi.org/10.1590/S180759322009000800007 